\title{
Preliminary Investigations of the Anti-asthmatic Properties of the Aqueous Extract of Justicia pectoralis (Fresh Cut)
}

C Cameron, AS Jacob, EA Thomas, AS Levy

\begin{abstract}
Background: Justicia pectoralis (fresh cut plant), family Acantheceae, is a herb that is native to central America and the Caribbean. A crude extract prepared from the leaves of Justicia pectoralis is commonly used in Jamaican ethnotraditional medicine to reduce difficulty in breathing and suppress wheezing in asthmatic individuals.

Objectives: To investigate the anti-inflammatory and antihistamine activity of an aqueous extract of Justicia pectoralis.

Method: In in vivo experiments, guinea pigs were sensitized by the method of Weinrich and Undem, 1987. The effect of water on the wheals was assessed in the control group, $n=4$. The effect of $3.3 \mathrm{mg}$ of the crude extract was noted in histamine-induced wheals over a period of three hours. The extract was injected via intraperitoneal injections. In in vitro experiments, $3.3 \mathrm{mg}$ of crude sample was tested for its effectiveness against histamine-induced tracheal contraction caused by cumulative dosing of histamine. Results: The crude extract was efficacious in reducing the formation of histamine-induced wheals $(\mathrm{p}<$ 0.05). Results obtained from in vitro studies indicated that the crude extract $(3.3 \mathrm{mg})$ caused significant reduction in tracheal smooth muscle contraction resulting from cumulative doses of histamine ( $\mathrm{p}<0.05)$. However, as the histamine doses increased, fresh cut extract was not able to maintain inhibition of histamine-induced tracheal smooth muscle contraction. This is an indication that the extract showed competitive reversible antagonism, possibly at histamine receptors.

Conclusion: A crude extract of the leaves of Justicia pectoralis reduced the formation of histamine-induced wheals in sensitized guinea pigs $(p<0.05)$ and also reduced histamine-induced tracheal smooth muscle contractions $(\mathrm{p}<0.05)$. It blocked the effect of contraction produced by histamine in the airways; this property supports folklore claims for its use as an antihistamine.
\end{abstract}

Keywords: Asthmatic, Justica pectoralis, trachea, wheals

\section{Investigaciones Preliminares de las Propiedades Antiasmáticas del Extracto Acuoso de Justicia pectoralis (Té Criollo)}

C Cameron, AS Jacob, EA Thomas, AS Levy

\begin{abstract}
RESUMEN
Antecedentes: Justicia pectoralis (conocida como "té criollo", "tilo", o "hierba de carpintero") es una hierba de la familia de las acantáceas, nativa de América central y el Caribe. Un extracto crudo preparado de las hojas de Justicia pectoralis se utiliza comúnmente en la medicina etnotradicional de Jamaica para reducir la dificultad en la respiración y suprimir las sibilancias en los individuos asmáticos. Objetivos: Investigar la actividad antiinflamatoria y antihistamínica de un extracto acuoso de Justicia pectoralis.

Método: En experimentos in vivo, conejillos de Indias fueron sensibilizados por el método de Weinrich $y$ Undem (1987). El efecto del agua sobre las ronchas fue evaluado en el grupo control, $n=4$. El efecto de $3.3 \mathrm{mg}$ del extracto crudo fue observado en las ronchas inducidas por la histamina por un periodo de tres horas. El extracto se inyectó por vía intraperitoneal. En experimentos in vitro, una muestra de 3.3
\end{abstract}

From: The University of the West Indies, Section of Pharmacology, Department of Basic Medical Sciences, Kingston 7, Jamaica.
Correspondence: Dr AS Jacob, The University of the West Indies, Department of Basic Medical Sciences, Section of Pharmacology, Kingston 7, Jamaica. E-mail: audrey.jacob@uwimona.edu.jm 
mg de extracto crudo fue sometida a prueba para investigar su efectividad contra la contracción traqueal inducida por la histamina, como consecuencia de la acumulación de dosis de histamina.

Resultados: El extracto crudo fue eficaz en reducir la formación de ronchas inducidas por la histamina $(\mathrm{p}<0.05)$. Los resultados obtenidos a partir de los estudios in vitro indicaron que el extracto crudo (3.3 $\mathrm{mg}$ ) causaba una reducción significativa de la contracción del músculo liso traqueal resultante de las dosis acumulativas de histamina $(\mathrm{p}<0.05)$. Sin embargo, a medida que se aumentaba la dosis de histamina, el extracto de té criollo no era capaz de mantener la inhibición de la contracción del músculo liso traqueal inducida por la histamina. Esto indica que el extracto mostró un antagonismo competitivo reversible, posiblemente en los receptores de histamina.

Conclusión: La muestra de extracto crudo de las hojas de Justicia pectoralis redujo la formación de ronchas inducidas por histamina en cobayos sensibilizados ( $\mathrm{p}<0.05)$, y también redujo las contracciones del músculo liso traqueal inducidas por la histamina $(\mathrm{p}<0.05)$. El extracto bloqueó el efecto de la contracción producida por la histamina en las vías respiratorias - propiedad que respalda el criterio de la medicina etnotradicional en cuanto a su uso como antihistamínico.

Palabras claves: Asma, Justicia pectoralis, tráquea, ronchas

West Indian Med J 2015; 64 (4): 321

\section{INTRODUCTION}

According to estimates made by the World Health Organization, 300 million people suffer from asthma and 255000 people died from this disease in 2005 (1). Asthma is also an important public health issue in Jamaica. In government hospitals in Jamaica, five per cent of clinic visits are asthma related and 25 per cent of respiratory conditions related to asthma are admitted to hospital (2).

Asthma is a disease that affects the bronchioles, causing bronchial hyper-responsiveness, inflammation of the epithelium, increase in mucus secretion, oedema and smooth muscle contraction (3) mediated through the release of numerous inflammatory players including histamine (4) and leukotrienes (5). This results in narrowing of the airways, decrease in airflow and difficulty in breathing. In an asthma attack, the diameter of the trachea is reduced and free movement of air is altered since the trachea contracts due to bronchospasm which causes narrowing of airways (6). Therefore, in evaluating the anti-asthmatic property of an extract, the antihistaminic and bronchodilator properties can be used as pharmacodynamic parameters. Since inhibition of histamine-induced tracheal contraction is an established screening model for bronchidilator activity (7), and inhibition of histamine-induced wheal formation is commonly used as a measure of effectiveness against inflammation (8), we utilized both of these models in the screening of Justica pectoralis for its anti-asthmatic properties.

Justicia pectoralis is a domestic herb belonging to the family Acantheceae and common to Jamaica, other West Indian islands, Mexico and tropical South America. In Jamaica, the plant grows naturally in many locations; it is about $3 \mathrm{~cm}$ tall with grass-like foliage which takes on a purple-tinge as it gets older. The flowers present with tiny two-lipped petals that are essentially white with pink or lavender in colour (9). Numerous pharmacological actions of the Justicia pectoralis plant have been reported including bactericidal, oestrogenic, anxiolytic and anti-epileptic activities (10). Additionally, antinociceptive, bronchodilator and anti-inflammatory effects of the plant have also been documented (11). In Jamaican folklore practice, the leaves of this plant are used to make a tea which is taken by asthmatics to reduce the difficulty in breathing. This anti-asthmatic claim, however, has not been fully validated.

On the basis of this ethno-traditional practice, the present preliminary study was undertaken to investigate the action of Justicia pectoralis leaf extract for its anti-asthmatic activity. We evaluated the ability of the crude extract of the leaves of Justicia pectoralis to inhibit experimental histamineinduced events that are considered to be classical hallmarks of extrinsic asthma (12). The screening involved testing the ability of the extract to inhibit histamine-induced tracheal contraction in vitro and wheal formation in vivo. Our results support further investigations into the bronchiodilatory mechanisms of Justicia pectoralis in future studies.

\section{SUBJECTS AND METHOD}

The following were needed for the experiment: guinea pigs 250-400 g, polygraph grass instruments, sodium pentobarbital (Sigma Aldrich), histamine bisphosphate (BDH), Whatman \#2 filter paper, rotary evaporator (Buchi Instruments) and analytical balance (Texas Instruments).

\section{Preparation of sample}

Justicia pectoralis (fresh cut plant) was collected and authenticated by Mr Patrick Lewis of the Botany Section, The University of the West Indies, Mona campus.

Leaves (150 g) of Justicia pectoralis, free of contamination with fungus and insect eggs, were washed in $1 \%$ detergent and air dried. The extract was prepared by the decoction method; $23.72 \mathrm{~g}$ of the fresh leaves were boiled in $273.2 \mathrm{~L}$ of 
water for fifteen minutes and allowed to stand for thirty minutes. The solution was filtered through Whatman \# 2 filter paper and stored in dark glass bottles at $4{ }^{\circ} \mathrm{C}$.

\section{Ethical approval and animals}

The animals were acclimatized in the experimental animal house for one week before the start of investigations. The animals, in cages under standard conditions (ambient temperature, $28.0+2.0{ }^{\circ} \mathrm{C}$, and humidity $46 \%$, with a 12 -hour light/dark cycle), were given water and chow. All the rats in both test and control groups were allowed free access to food and water ad libitum for duration of the tests. Good hygiene was maintained by constant cleaning and removal of faeces and spilled feed from cages daily.

Ethical approval was granted by the Ethics Committee of the University Hospital of the West Indies/University of the West Indies/Faculty of Medical Sciences.

\section{Trachea smooth muscle preparation}

The trachea was removed from guinea pigs $(n=4)$ which were sacrificed by an overdose of $75 \mathrm{mg} / \mathrm{kg}$ sodium pentobarbital intraperitoneally. Connective tissue was removed and the tracheal strip was cut along the length opposite the trachealis muscle (13). The trachea was placed in a Petri dish containing Krebs-Hensleit solution $(\mathrm{mM}): 118$, potassium chloride $(\mathrm{KCl})$ 5.9 , magnesium sulfate $\left(\mathrm{MgSO}_{4}\right) 1.2$, calcium chloride $\left(\mathrm{CaCl}_{2}\right)$ 2.5 , sodium phosphate $\left(\mathrm{NaHPO}_{4}\right)$ 1.2, sodium bicarbonate $\left(\mathrm{NaHCO}_{3}\right) 23.5$ and glucose, 5.05. This physiological solution was maintained at $37^{\circ} \mathrm{C}$ and aerated with $95 \%$ oxygen $\left(\mathrm{O}_{2}\right)$ and $5 \%$ carbon dioxide $\left[\mathrm{CO}_{2}\right]$ (14). Subsequently, the tissue was cut into $2 \mathrm{~mm}$ lengths for use in experiments.

\section{In vitro experiments}

The polygraph was used to measure isometric tension of the tracheal muscle. The tracheal smooth muscle was mounted by attaching a piece of thread to both ends of the tissue with one end fixed to the L-shaped hook in the tissue bath $(10 \mathrm{~mL})$ containing Krebs solution, and the other fixed to a stainless steel wire attached to a force displacement transducer under tension

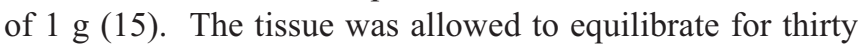
minutes while the bath was constantly aerated and maintained at $37^{\circ} \mathrm{C}$.

Cumulative doses of $1 \mu \mathrm{g}, 2 \mu \mathrm{g}, 4 \mu \mathrm{g}$ and $8 \mu \mathrm{g}$ of histamine were injected into the organ bath for control readings, with two-minute intervals between additions. Changes in isometric tension of the strip were measured by a force displacement transducer attached to a polygraph. The organ bath was washed twice and then allowed to re-equilibrate for $10 \mathrm{~min}$ utes and regain baseline. In test experiments, tensions in the histamine-induced tracheal tissue were recorded in the presence of $3.3 \mathrm{mg}(0.4 \mathrm{~mL})$ of the Justicia pectoralis extract. Log doses dependent response curves were plotted and the paired student's $t$-test was use to assess data.

\section{Sensitization}

Guinea pigs ( $n=4 /$ group) were placed in two groups and were sensitized with $0.1 \mathrm{~mL}$ of $10 \mathrm{mg} / \mathrm{kg}$ ovalbumin every other day for three days. Then after 21 days of the last injection, they were tested.

The flanks of all animals were shaven to describe clean circular areas, two anterior and two posterior in all animals. The right flanks of all the animals were given subcutaneous injections of $0.1 \mathrm{~mL}$ water containing $100 \mu \mathrm{g} / \mathrm{mL}$ of histamine; control groups were treated similarly with $0.1 \mathrm{~mL}$ water. Intraperitoneal injections were administered to the test group; these animals were treated with $3.3 \mathrm{mg}$ of crude extract in a volume of $0.1 \mathrm{~mL}$ of water. The control subjects were given intraperitoneal injections of $0.1 \mathrm{~mL}$ of distilled water. All wheal diameters were measured at 30-minute intervals for a period of two hours. Eight hours after measurement of wheal, animals were returned to the animal house for care.

\section{RESULTS}

Justicia pectoralis extract (3.3 mg) caused progressive relaxation of the trachea pre-contracted with cumulative doses of histamine $[1 \mu \mathrm{g}$ to $8 \mu \mathrm{g}, p<(0.05)]$ (Fig. 1). However, with doses higher than $8 \mu \mathrm{g}$, contractile tension in the tissue increased (Fig. 1) at $-4.2 \log$ dose concentration value. In the presence of $3.3 \mathrm{mg}$ extract, the histamine-induced wheals showed a continuous decrease in percentage change of wheal diameter, $p<0.05$ (Fig. 2). These preliminary results indicate that Justicia pectoralis extract displays both antihistamine and anti-inflammatory activity.

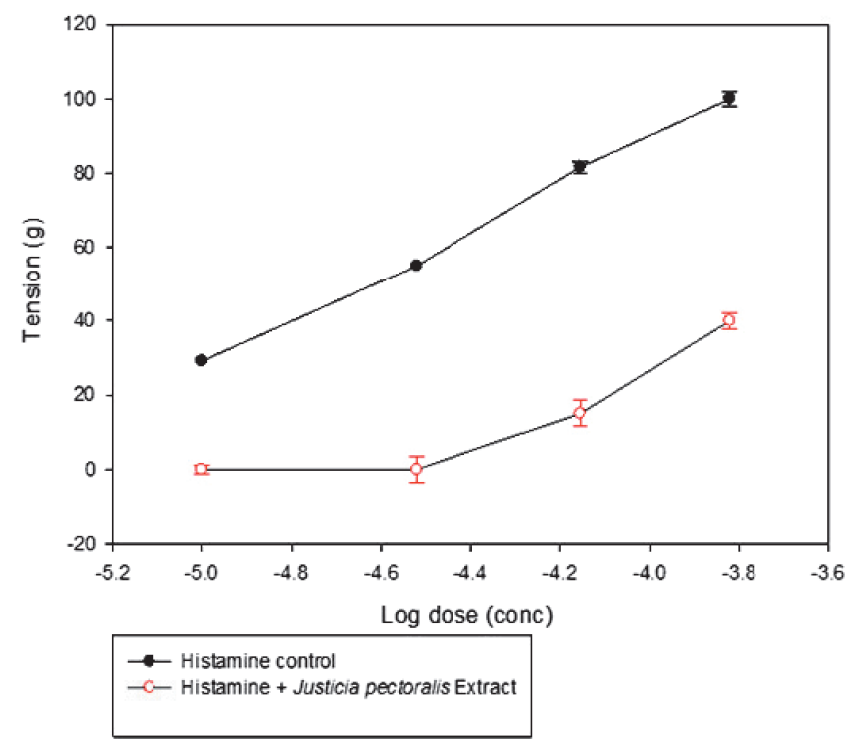

Fig. 1: Graph showing the response of the trachea to histamine-induced contractions in the presence of Justicia pectoralis extract. Each data point represents the mean \pm standard error of the mean (SEM) for $\mathrm{n}=4 .{ }^{*} p<0.05$ (paired Student's $t$-test) 


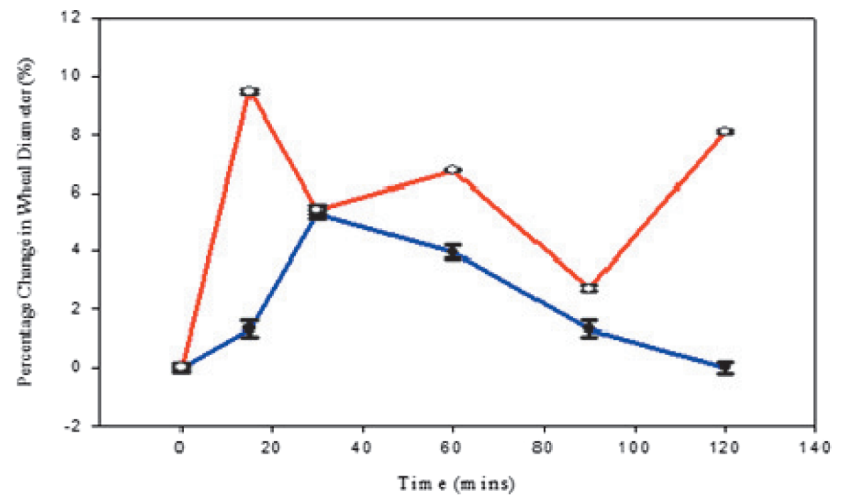

$$
\begin{aligned}
& 0 \text { Time vs Ex. } \mathrm{H} \text { istamine } \\
& 0 \text { Time vs cON.Histamine }
\end{aligned}
$$

Fig. 2: Effect of aqueous extract of Justicia pectoralis on histamine-induced wheals. Each data point represents the mean \pm standard error of the mean (SEM) for $\mathrm{n}=4 ; p<0.05$ (paired Student's $t$-test).

\section{DISCUSSION}

Traditional folk medicine can be used as a guide in continuing the search for new natural products with potential medicinal properties (16). In Jamaica, the aqueous extract of Justicia pectoralis is used in folklore practice for the suppression and prevention of asthmatic symptoms. Justicia pectoralis extract is used mainly to treat extrinsic or allergic type asthma since it is often triggered by the presence of allergens such as spores, pollen dust and animal dander on farm lands.

Fresh cut plant was prepared by the decoction method and used in all experiments to test for activity against histamine-induced tracheal contraction and change in cutaneous wheal diameter over a period of time. The guinea pig trachea was used in all experiments. Guinea pig tracheal smooth muscle is suitable for in vitro evaluation of anti-asthmatic drugs, since the airway anatomy and the response to inflammatory mediators is similar to humans (17). Asthmatic response can be measured and airway hyper-responsiveness is observed in vitro and in vivo. The usefulness of the guinea pig trachea is well documented by Humbles et al (18), since all histamine receptor sub types, $\mathrm{H}_{1} \mathrm{H}_{2}$ and $\mathrm{H}_{3}$, are present in this tissue (19).

Justicia pectoralis extract caused progressive relaxation of the trachea treated with cumulative doses of histamine, $p<$ 0.05 (Fig. 1). However, with doses higher than $8 \mu \mathrm{g}$, contractile tension in the tissue increased (Fig. 1) at -4.2 log dose concentration value. This depicts competitive inhibition, in which the competitor binds to the active site of the substrate and prevents the substrate from binding due to similar structural properties (20). In this instance, the extract acted as a competitive inhibitor, and this type of inhibition is reversible.

Asthma is associated with some degree of inflammation, leading to reduced tracheal diameter and difficulty in breathing (21). The anti-inflammatory effect of Justicia pectoralis was tested by noting its action on wheals in sensitized guinea pigs. Mast cells are in proximity with blood vessels and nerves subcutaneously and wheal forms as a result of exudation of fluid from small blood vessels such as the capillaries and venules due to vasodilation. The introduction of ovalbumin after sensitization heightens the immune system of the guinea pig leading to an immediate allergic reaction (22). The extract caused a gradual reduction in histamine-induced wheal diameter, $p<0.05$ (Fig. 2).

Our findings are consistent with that of other authors (10) as it relates to the anti-inflammatory actions of the aqueous fresh cut extract. Also, it is of significance to note that Justicia pectoralis extract produces bronchodilatory effect on carbachol $(0.3 \mu \mathrm{M})$-induced tracheal muscle contraction (11). Carbachol is a muscarinic agonist and acts via $\mathrm{M}_{3}$ receptors (23) to produce contractions. It is possible that the anti-muscarinic component of Justicia extract acted in synergism with the antihistamine component to collectively produce tracheal smooth muscle relaxation. Further studies can validate receptor profile.

\section{CONCLUSION}

This study concludes that aqueous Justicia pectoralis demonstrated both antihistamine and anti-inflammatory actions $(p<$ $0.05)$. This therefore suggests that the extract may be able to prevent and alleviate the symptoms of asthma as claimed by folklore practices. However, further studies are required to identify the bioactive components and fully characterize this extract pharmacologically.

\section{REFERENCES}

1. World Health Organization. Asthma. Fact sheet no. 307. Geneva, Switzerland; WHO; 2008. Available from: http://www.who.int/mediacentre/factsheets/fs307/en/

2. Knight-Madden J, Forrester TE, Hambleton IR, Lewis N, Greenough A. Skin test reactivity to aeroallergen in Jamaicans: relationship to asthma. West Indian Med J 2006; 55: 142-7.

3. Lugogo N, Que LG, Fertel D, Kraft M. Asthma. In: Mason RJ, Broaddus VC, Martin TR, King TR Jr, Schraufnagel DE, Murray JF et al, eds. Murray and Nadel's Textbook of Respiratory Medicine. $5^{\text {th }}$ ed. Philadelphia: Elsevier Saunders; 2010; 945-55.

4. Berend N, Salome CM, King GG. Mechanisms of airway hyper responsiveness in asthma. Respirology 2008; 13: 624-31.

5. Hart P. Regulation of inflammatory response in asthma by mast cell products. Immunol Cell Biol 2001; 79; 149-53.

6. Zeki AA, Schivo M, Chan A, Albertson TE, Louie S. The Asthma-COPD overlap syndrome: a common clinical problem in the elderly. J Allergy (Cairo) 2011; 2011: 861926. doi: 10.1155/2011/861926.

7. Centers for Disease Control and Prevention. National Hospital Ambulatory Medical Care Survey, 2009. Atlanta, GA: CDC, National Center for Health Statistics; 2009.

8. Priyashree S, Jha S, Pattanayak SP. Bronchodilatory and mast cell stabilising activity of Cressa cretica L.: evaluation through in vivo and in vitro experimental models. Asian Pac J Trop Med 2012; 5: 180-6. doi: 10.1016/S1995-7645(12)60021-2.

9. Robertson D. Jamaican herbs-nutritional and medicinal values. Kingston: Jamaica Herbs Limited; 1988: 24-31.

10. Corrêa GM, Alcântara AF de C. Chemical constituents and biological activities of species of Justicia - a review. Braz J Pharmacogn 2012; 22: 220-38.

11. Leal LKAM, Ferreira AAG, Bezerra GA, Matos FJA, Viana GSB. Antinociceptive, anti-inflammatory and bronchodilator activities of Brazilian medicinal plants containing coumarin: a comparative study. J Ethnopharmacol 2000; 70: 151-9. 
12. Black JL, Roth M. Intrinsic asthma: is it intrinsic to smooth muscle? J Clin Exp Allergy 2009; 31: 962-5.

13. Saito M, Shibata O, Yamaguchi M, Yoshimura M, Makita T, Harada N et al. Metoclopramide causes airway smooth muscle relaxation through inhibition of muscarinic M3 receptor in the rat trachea. Anesth Analg 2004; 98: 1325-9.

14. Ichinose M, Stretton C, Schwartz JC, Barnes PJ. Histamine, $\mathrm{H}_{3}$-receptors inhibit cholinergic neurotransmission in guinea-pig airways. Br J Pharmacol 1989; 97: 13-5. Available from: http://www.ncbi.nlm.nih. gov/pmc/articles/PMC1854483/

15. Plotz SG, Traidl-Hoffmann C, Feussner I, Kasche A, Feser A, Ring J et al. Chemotaxis and activation of human peripheral blood eosinophils induced by pollen-associated lipid mediators. J Allergy Clin Immunol 2004; 113: $1152-60$.

16. Zeid AHS, Hifnawy MS, Sleem AA, Mohamed RS. Chemical constituents and anti-inflammatory activity of the aerial parts of Calliandra haematocephala Hassk. Planta Med 2007; 73: 20-3.

17. Irvin CG. Neutrophils, airway hyperresponsiveness and COPD: true, true and related? Eur Respir J 2012; 40: 1067-9. doi: 10.1183/09031936. 00129912 .
18. Humbles AA, Conroy DM, Marleau S, Rankin SM, Palframan RT, Proudfoot $\mathrm{AE}$ et al. Kinetics of eotaxin generation and its relationship to eosinophil accumulation in allergic airways disease: analysis in a guinea pig model in vivo. J Exp Med 1997; 186: 601-12.

19. Parsons ME, Garellin CR. Histamine and its receptors. Br J Pharmacol 2006; 47 (Suppl 1): S127-S135.

20. Kenakin TP. The Schild Regression in the process of receptor classification. Can J Pharmacol 1982; 60: 249-65.

21. Yagi R, Nagai H, ligo Y, Akimoto T, Arai T, Kubo M. Development of atopic dermatitis-like skin lesions in STAT6-deficient NC/Nga mice. J Immunol 2002; 168: 2020-7.

22. Dombret A, Aubier MC, Pretolani M. Airway structural alterations selectively associated with severe asthma. Am J Respir Crit Care Med 2003; 67: 1360-8.

23. Kitazawa T, Hirama R, Masunaga K, Nakamura T, Asakawa K, Cao J et al. Muscarinic receptor subtypes involved in carbachol-induced contraction of mouse uterine smooth muscle. Naunyn Schmiedebergs Arch Pharmacol 2008; 377: 503-13. 